\title{
GIS Based Analysis of Biophysical and Socio - Economic Factors for Land Degradation in Kandaketiya DS Division
}

\author{
K.D.B.L. Jayarathne, N.D.K. Dayawansa ${ }^{1}$ and R. P. De Silva ${ }^{1}$ \\ Postgraduate Institute of Agriculture \\ University of Peradeniya \\ Peradeniya, Sri Lanka
}

\begin{abstract}
Soil erosion is one of the major factors that contributes to land degradation in the up and mid country of Sri Lanka. It is important to assess the rate of soil erosion under different environmental and socio-economic contexts to identify and apply suitable management interventions. A number of parametric models have been developed to predict soil erosion at drainage basins. Yet Universal Soil Loss Equation (USLE) is the most widely used empirical equation for estimating annual soil loss from small agricultural lands.
\end{abstract}

This study was carried out with the objective of developing a land degradation assessment model using a geospatial approach. The study area was Kandaketiya DS division in Badulla district. USLE together with some socio - economic factors were used to develop the model for predicting land degradation. Slope length $(L)$ and slope gradient $(S)$ factors were derived from Digital Elevation Model. Rainfall erosivity $(R)$ factor was determined using a correlation developed for Sri Lanka in a past research. Soil erodibility $(K)$ factor was derived from the soil map. Crop management $(C)$ factor and Erosion control practices $(P)$ factor related to land cover derived from remotely sensed data taken from the literature. Annual soil erosion was computed using the above factors. The computed soil erosion map was coupled with the socioeconomic factors on population density, agricultural land to man ratio, land to man ratio and number of Samurdhi beneficiaries to assess the land degradation severity. The results showed that marginal tea lands are the highest contributor to soil loss in the study area. According to the study, soil erosion and population density contributed more to the land degradation. A strong negative relationship was found between land degradation and land to man ratio.

\section{INTRODUCTION}

Land degradation in terms of soil erosion is a complex process and its multiple hidden social and environmental impacts are an increasing threat for the human existence (Hesadi et al., 2003). Land degradation can happen either as a result of natural hazards or inappropriate land management practices (RRCAP/UNEP, 1992).

Assessment of land degradation can vary depending on the type of degradation process, the scale of assessment and the method of assessment. Soil erosion is one of the main causes of land degradation and can be quantified by field experiments or predicted by using models. The Universal Soil Loss Equation (USLE) has been designed as a method to predict average annual soil loss caused by sheet and rill erosion. However, the USLE is often criticized for its lack of applications (Castro et al., 2001). Currently, it is possible to estimate the sediment load from watersheds through mathematical modeling approaches.

Department of Agricultural Engineering, Faculty of Agriculture, University of Peradeniya, Sri Lanka 
Land degradation models particularly concern about runoff and soil erosion. Also, they are used to identify complex interactions between physical and socio-economic processes. It is widely accepted that satellite remote sensing and Geographical Information Systems offer considerable advantages for land degradation assessments with a comprehensive spatial coverage and analytical capabilities.

Land degradation is a major problem in Kandaketiya DS Division in Badulla District. However, there is a considerable spatial heterogeneity exists within this area in terms of land use, topography, land management and socio-economic conditions. Therefore, land degradation assessment studies are very important for the sustainable development of the area. Considering the above background, this study was conducted with the objectives of developing a land degradation assessment model using a geospatial approach.

\section{MATERIALS AND METHODS}

\section{Materials}

The following spatial and non spatial data were used in this study: Spatial data on Contour, Soil, Land use, Streams, Reservoirs, Roads; 1:50,000 scale topographic maps of the Survey Department of Sri Lanka; demographic data (Population Density, Education, Income, Land to man ratio, and agro land to man ratio); ground truth information and Arc GIS and Arc View 3.3 software for GIS analysis.

\section{Study Area}

This study was carried out at Kandaketiya DS division in Badulla District. It is located in latitudes $70^{\circ} 10^{\prime} \mathrm{N}$ to $70^{\circ} 14^{\prime} \mathrm{N}$ and longitudes $80^{\circ} 01^{\prime} \mathrm{E}$ to $81^{\circ} 03^{\prime} \mathrm{E}$ within the Wet Zone of Sri Lanka. The total extent is about 15,666 ha. Annual rainfall is about $2250 \mathrm{~mm}$. Mountain rain forest and grasslands are found as major vegetation types. The main soil type is Red Yellow Podzolic. The total population and mean population density are 23,929 and 156/km² respectively The location of Kandaketiya DS Division is shown in Fig. 1.

\section{Methdology}

\section{a) Preparation of spatial data layers}

Digital Elevation Model (DEM) was prepared by using contour lines $(10 \mathrm{~m})$ digitized from the topographic maps. The DEM was used to generate slope and aspect maps.

\section{b) Determination of factors of USLE}

The procedure adopted to determine factors of USLE is given below. 


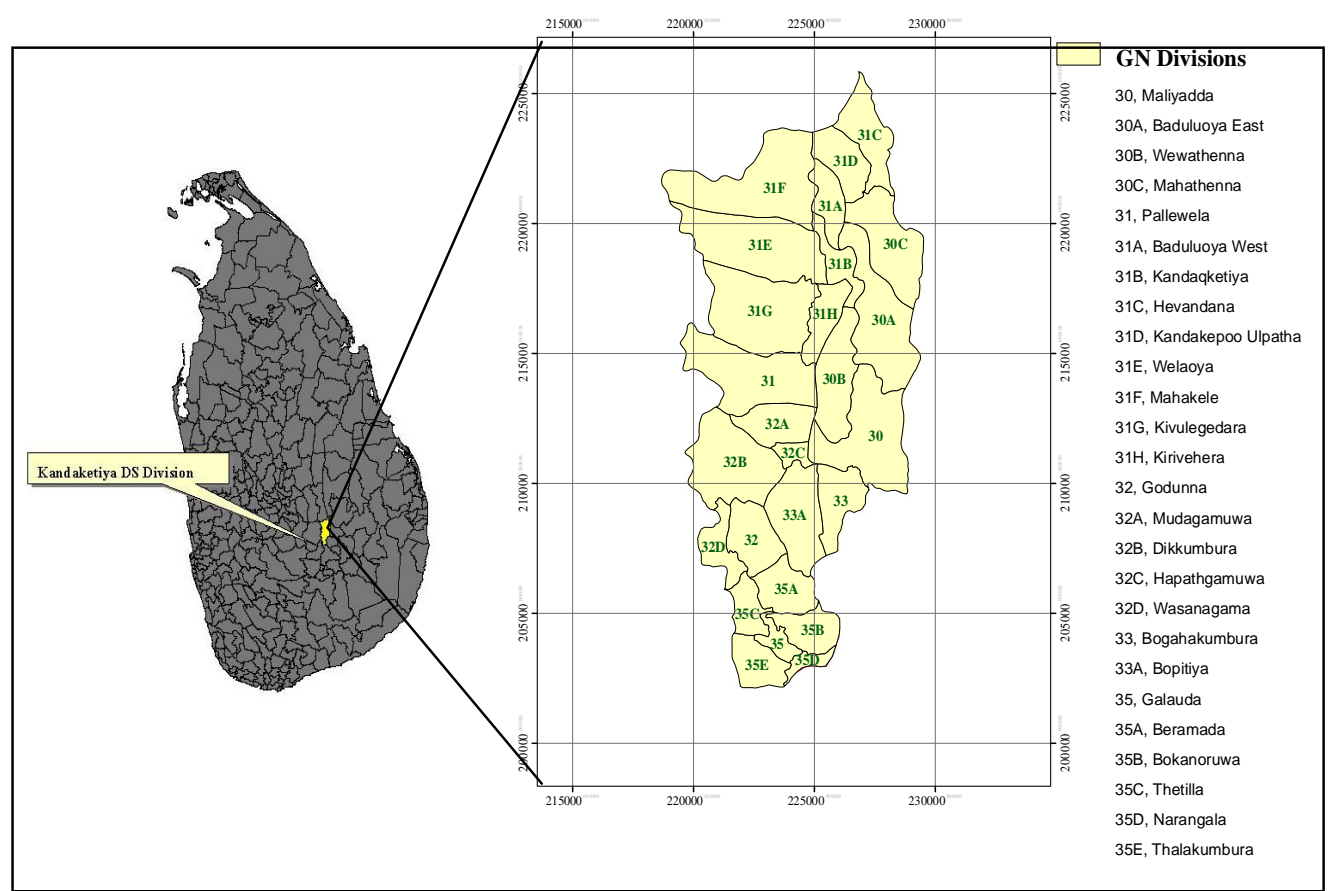

\section{Fig. 1. Location of Kandaketiya DS Division}

\section{Rainfall erosivity (R) factor}

Rainfall erosivity is calculated from the annual summation of rainfall energy in every storm (correlates with raindrop size) times during its maximum 30 minutes intensity. As expected, it varies geographically. $\mathrm{R}$ factor was determined from the average annual rainfall value using a correlation developed for Sri Lanka (Wijesekera and Samarakoon, 2001). In this, the rainfall erosivity was equated to $(972.75+9.95 *$ Annual Rainfall)/100).

\section{Slope coefficient (LS) factor}

The LS factor was created from the slope and aspect maps derived from the DEM. Other parameters of $\mathrm{L}$ and $\mathrm{S}$ factors were calculated by the equations 1 and 2 as described by Wijesekera and Samarakoon (2001).

$$
\text { Slope length factor }=(\mu / 72.6)^{\mathrm{m}}
$$

Where, $\mu$ is slope length and $\mathrm{m}$ is a slope dependent parameter. Value for $\mathrm{m}$ was taken as 0.3 for slopes less than 5\%, 0.6 for slopes greater than $10 \%$ and 0.5 for slopes in between.

Slope gradient factor $(S)=\left(0.43+0.3 \mathrm{~s}+0.043 \mathrm{~s}^{2}\right) / 6.613$

(Where, $\mathrm{s}$ is the slope gradient in percentage).

\section{Soil erodibility (K) factor}

This factor quantifies the cohesive or bonding character of a soil and its resistance to dislodging and transport due to raindrop impact and overland flow. The K factor of Red Yellow Podzolic soil as main soil type was considered as 0.22 . 


\section{Crop management $(C)$ factor and Erosion control practice $(P)$ factor}

$\mathrm{C}$ factors of the model were taken from published information related to land cover of the study area. $\mathrm{P}$ factors were determined using the soil conservation methods practiced in different land uses in Sri Lanka since conservation practices of land use could be easily correlated with land cover. The main land use type in the area is scrub jungle. C-factor and $\mathrm{P}$-factor values for main land use type are 0.011 and 1.00 respectively.

\section{c) Preparation of erosion intensity map}

All maps representing R, K, LS, C and P factors were integrated to generate a composite map of soil erosion.

\section{d) Preparation of socio-economic layers}

The socio-economic database was obtained from Kandaketiya Divisional Secretarial Office. Thematic layers of socio-economic factors were prepared by performing interpolation of point level socio-economic data such as population density, agricultural land to man ratio, land to man ratio and number of Samurdhi beneficiaries at GN scale.

\section{e) Development of land degradation severity map}

The land degradation severity map was prepared by integrating all spatial data layers. Weights were given to each spatial data layers according to their possible contribution towards soil erosion. Since rainfall induced soil erosion is the most influential factor in land degradation, more weight was assigned to this data layer during the analysis. The assigned weightage values are shown in Table 1.

Table 1. Weightage values for different spatial data type

\begin{tabular}{lc}
\hline Spatial data type & Weightage (\%) \\
\hline Soil loss & 45 \\
Population density & 25 \\
Agro land-man ratio & 15 \\
Land-man ratio & 10 \\
Samurdhi beneficiaries & 5 \\
\hline
\end{tabular}

Land degradation severity was assessed by using Weighted Sum algorithm in ArcGIS software. Applying simple arithmetic calculations, final land degradation map was produced.

\section{RESULTS AND DISCUSSION}

Fig. 2 shows the basic data layers such as digital elevation model (a), and Land Use map (b). The soil erosion severity map is presented in Fig. 3. 


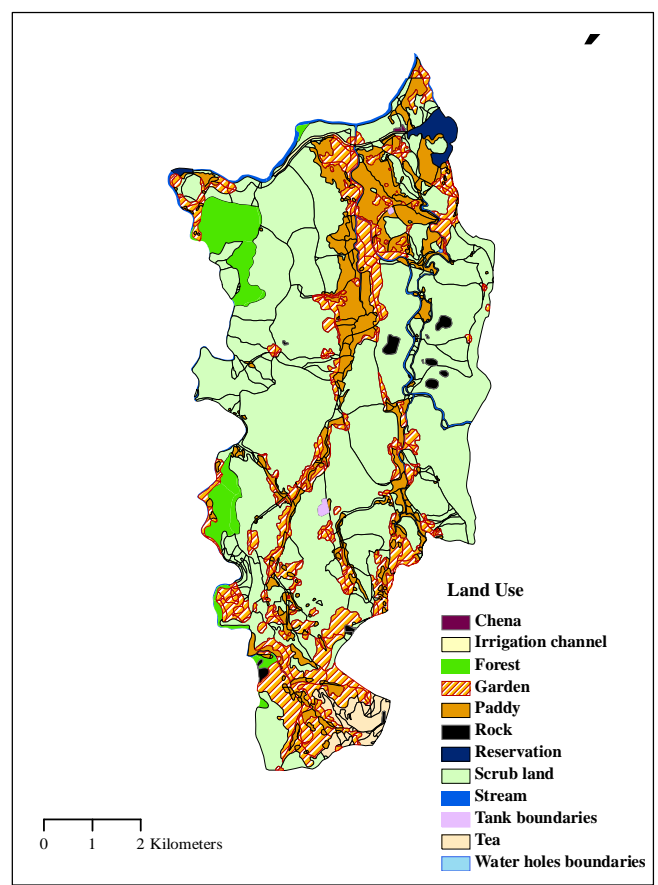

(a)

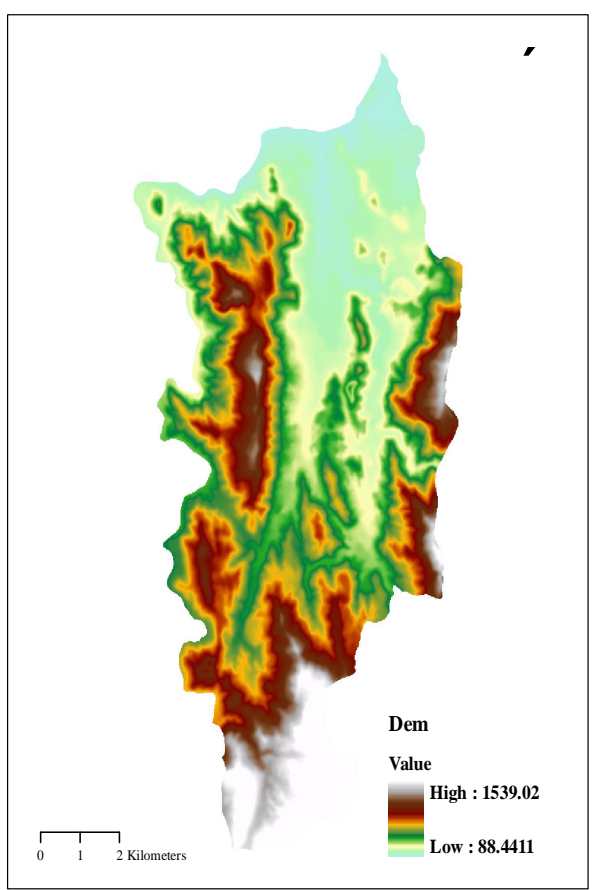

(b)

Fig. 2. Supportive data layers: (a) Digital Elevation Model and (b) Land Use Map

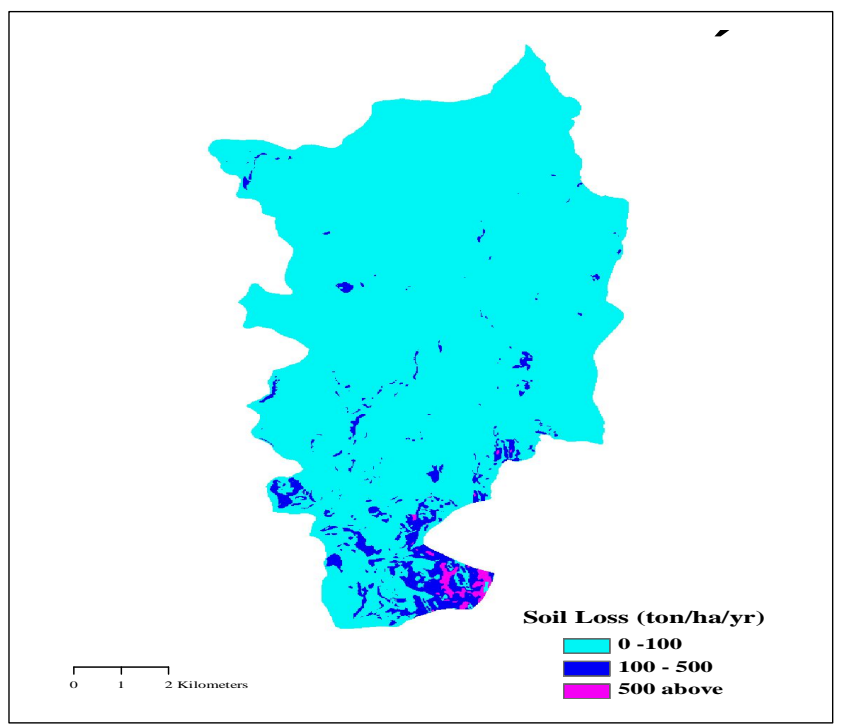

Fig. 3. USLE derived soil erosion severity in Kandaketiya DS division

\section{Soil erosion susceptibility}

According to the land use map (Fig. 02 (b)), large section of the study area (12,721 ha) is covered by forest and scrub with gentle slopes. The USLE estimated low soil loss from this 
area which range from 1-55 ton/ha/yr. The USLE calculated high soil losses in Bokanoruwa and Narangala GN divisions. More than $50 \%$ of the area in Bokanoruwa GN division is affected by severe soil erosion. The slope in this area ranged from $55 \%$ to $84 \%$.

\section{Assessment of land degradation in the study area}

The land degradation map of Kandaketiya DS Division which was prepared by integrating USLE estimated soil erosion and other socio-economic factors is presented in Fig. 4.

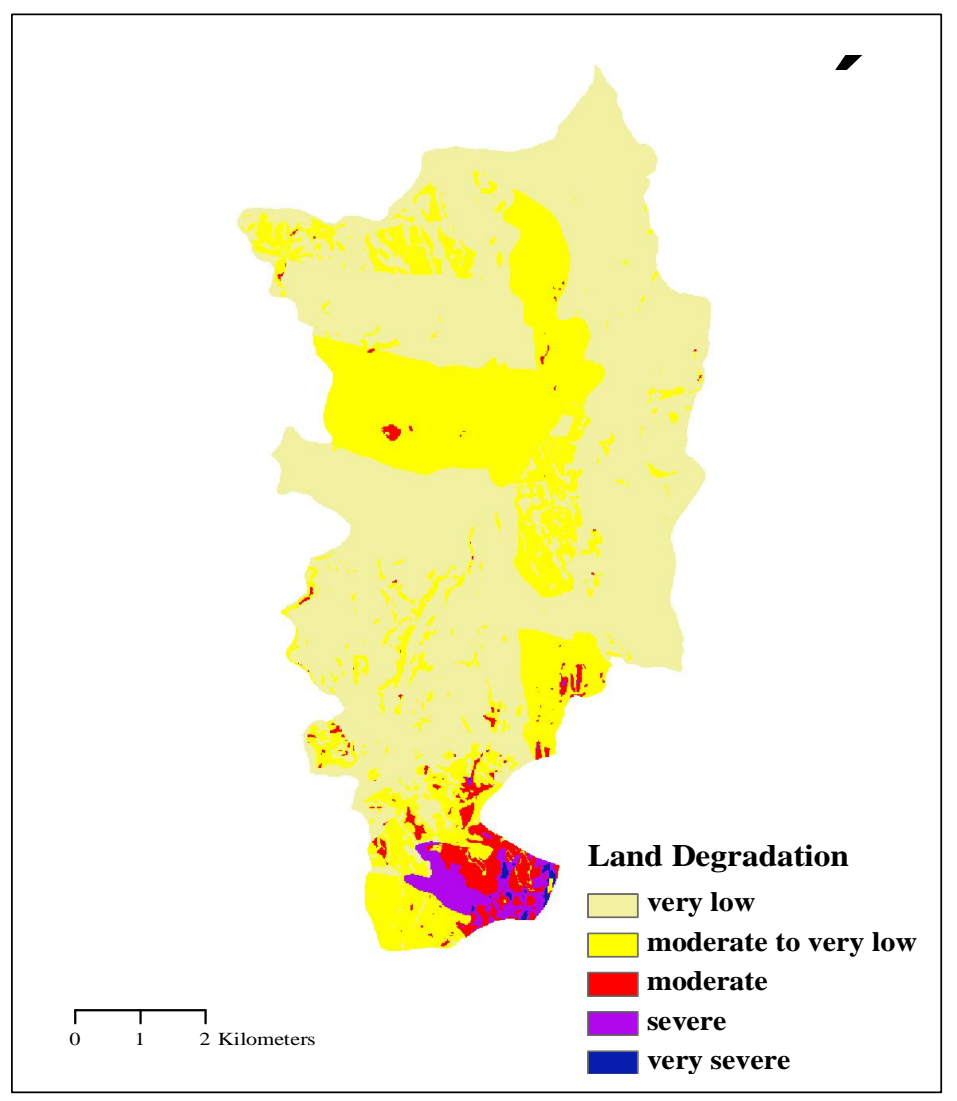

\section{Fig. 4. Land degradation map of Kandaketiya DS division.}

Very severe land degradation observed in both Narangala and Bokanoruwa GN divisions which showed high soil erosion rates. It was found that the estimated soil loss by USLE was directly related to land degradation severity. Both "very severe" and "severe" classes are fallen within "medium" and "high" soil erosion classes. In correlation analysis, correlation coefficient between population density and land degradation was 0.731 at $99 \%$ significance level. Therefore, it is obvious that increase of population seriously affect on land degradation. Galauda GN division, which consists of the highest population density is severely affected by land degradation. The high agricultural land to Man ration can be observed in both Maliyadda and Kandakepoo Ulpatha GN divisions. However, both GN divisions are fallen under "slight" land degradation class. The correlation analysis shows a poor negative correlation between agricultural land to man ratio and land degradation. When the extent of agricultural land per person is high, the land degradation severity decreases. 
Both Maliyadda and Kandakepoo Ulpatha GN divisions showed highest land-man ratio and slight land degradation. According to the correlation analysis, there is a strong negative relationship between land degradation and land to man ratio. Accordingly, when the per capita land availability is high susceptibility to land degradation becomes less.

The numbers of Samurdhi beneficiaries of each GN division reflect the poverty level in the GN division. Severe and very severe land degradation areas were found where moderate number of Samurdhi beneficiaries live. According to the statistical analysis, the study could not identify any relationship between land degradation and poverty level.

\section{CONCLUSIONS}

Computed soil loss in the study area is ranging from 0 to more than $500 \mathrm{t} / \mathrm{ha} / \mathrm{yr}$. Annual soil loss from scrub and forest areas was the lowest whereas degraded tea lands contributed to very high soil losses.

There is a strong positive relationship between land degradation and soil erosion as well as land degradation and population density while strong negative relationship can be observed between land degradation and land to man ratio. A sound correlation could not be observed between land degradation and poverty level.

It is recommended to use multi-temporal, multi-sensor and multi-spectral remotely sensed data to provide valuable and very important factors in the USLE like C and P to assess soil erosion for this study.

\section{REFERENCES}

Castro Filho, C., Cochrane, T.A., Norton, L.D., Caviglione, J.H. and Johansson, L.P. (2001). Land degradation assessment: tools and techniques for measuring sediment load. Agric. Research Service, Purdue University, West Lafayette, USA.

Hesadi, H., Jalili, K. and Hesadi, M. (2003). Applying RS and GIS for Soil Erosion and Sediment Estimation by MPSIAC Model - A case study of Kenesht watershed in Kermanshah, Iran. [access 27 September, 2007]. http://www.gisdevelopment.net/application/ geology/geomorphology/geogmf001.htm.

RRCAP/UNEP, (1992). Part three: key national environmental issues. [access 27 September, 2007]. http://www.rrcap.unep.org/pub/soe/srilanka land.pdf.

Wijesekera, S. and Samarakoon. L. (2001). Extraction of parameters and modeling soil erosion using GIS in a GRID environment. [access 27 September, 2007]. Available from internet: http://www.crisp.nus.edu.sg/ acrs2001/pdf/169wijes. 